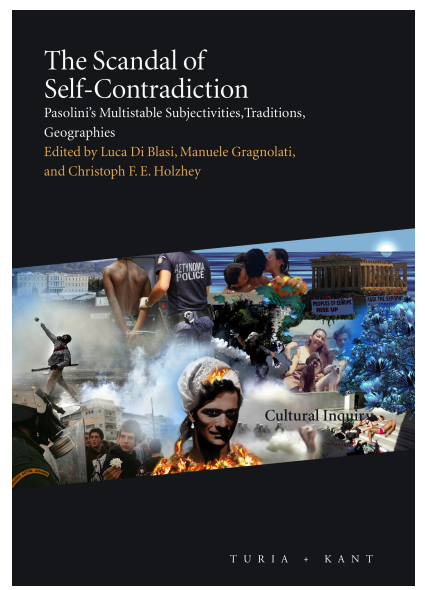

The Scandal of Self-Contradiction: Pasolini's Multistable Subjectivities, Geographies, Traditions, ed. by Luca Di Blasi, Manuele Gragnolati, and Christoph F. E. Holzhey, Cultural Inquiry, 6 (Vienna: Turia + Kant, 2012), pp. 189-207

PREVIOUSLY PUBLISHED AS:

| Identical except for DOI prefix 10.25620

\section{LUCA DI BLASI \\ One Divided by Another Split and Conversion in Pasolini's San Paolo}

CITE AS:

Luca Di Blasi, 'One Divided by Another: Split and Conversion in Pasolini's San Paolo', in The Scandal of Self-Contradiction: Pasolini's Multistable Subjectivities, Geographies, Traditions, ed. by Luca Di Blasi, Manuele Gragnolati, and Christoph F. E. Holzhey, Cultural Inquiry, 6 (Vienna: Turia + Kant, 2012), pp. 189-207<https://doi.org/10. 37050/ci-06_11>

\section{RIGHTS STATEMENT:}

(C) by the author(s)

This version is licensed under a Creative Commons AttributionShareAlike 4.0 International License.

ABSTRACT: While Christian churches dramatically lost ground during the last decades (at least in European societies), in this very period one of the major Christian figures, Saint Paul, attracted the interest of leading 'progressive' intellectuals and philosophers like Pier Paolo Pasolini, Alain Badiou, Slavoj Žižek, or Giorgio Agamben. In the following text, by focusing on Pasolini and his uncompleted film project San Paolo, I will concentrate on the notion of the split. 


\title{
ONE DIVIDED BY ANOTHER
}

\author{
Split and Conversion in Pasolini's San Paolo
}

Luca Di Blasi

\section{INTRODUCTION}

While Christian churches dramatically lost ground during the last decades (at least in European societies), in this very period one of the major Christian figures, Saint Paul, attracted the interest of leading 'progressive' intellectuals and philosophers like Pier Paolo Pasolini, Alain Badiou, Slavoj Žižek, or Giorgio Agamben. This might appear paradoxical, but perhaps it is not: disentwined from the formerly powerful arms of a Church whose existence substantially depended upon his writings, Paul could become, perhaps for the first time, a major object of philosophical, heterodox, and even atheist readings.

His special readability ${ }^{1}$ seems to be connected to the contemporary Western spiritual situation, which is poised between 'postmodern relativism' and particularism, on the one hand, and attempts to renew the notions of truth and universality, on the other. Paul, too, was somehow in a position between 'Jewish particularism' and 'Christian universalism'. He was a Jew and a Roman citizen; moreover, he was not only a Jew, but a member of a Jewish community in the diaspora. He spoke and thought in 'Greek', but a peculiar Greek, something like the Yiddish of the Ashkenazim - to put it in terms of Agamben's preference for neither-nor situations, 'neither Greek nor Hebraic'. ${ }^{2}$

With his conversion on the way to Damascus, Paul obviously experienced a radical shift: he took the position of those he had previously persecuted. The reported change of name illustrates the drama of his shift: from the kinglike Saulus, he became the lowest, smallest, Paulus, a mere remnant, just trash for the world, as Paul put it (I Cor. 4, 13). The Damascene event was not only a mystical, dramatic, perhaps even traumatic event, but it retrospectively became the starting point for Paul who, as a theologian, missionary, and preacher, would be the founder of various 'Christian' communities and by that token the 'founder of the Church' depicted and demonized again and again in times of widespread anti-Church criticism. 
In the following text, by focusing on Pasolini and his uncompleted film project San Paolo, written between 1966/1968 and 1974 and published posthumously in $1977,{ }^{3}$ I will concentrate on the notion of the split (the split in the structure of time and, above all, the split of the figure of Paul) and will thereby analyze more closely the very moment of Paul's Damascene conversion. In the second section I will use the multistable figure as a model in order better to understand certain ambivalences in Pasolini's Paul. In the end, I will briefly try to locate Pasolini's reading of the founder of the Church in a triangulation with two major contemporary philosophers, Alain Badiou and Giorgio Agamben.

\section{SAINT PAUL'S SPLIT}

As in other interpretations of classical and mythological figures, so in his reading of his namesake Paul, the Italian author and film director Pier Paolo Pasolini was interested in recovering and working out his own brokenness and dividedness. ${ }^{4}$ The basic operation of his San Paolo project consisted in transferring Paul to the present. He called this procedure the 'temporal use of force' ('violenza temporale', 2023). By this, he wanted to achieve what he described as his central message: 'San Paolo è qui, oggi, tra noi' (2023), ${ }^{5}$ creating a specific tension between Paul's 'old' or 'eternal' answers and the 'current' questions of the 'evangelized' ('gli evangelizzati'). This is what Pasolini perceived as the 'newest and most poetic' aspect of his approach:

E da qui nascerà il fatto più nuovo e forse poetico del film: le 'domande' che gli evangelizzati porranno a San Paolo saranno domande di uomini moderni, specifiche, circostanziate, problematiche, politiche, formulate col linguaggio tipico di nostri giorni; le 'risposte' di San Paolo, invece, saranno quelle che sono: cioè esclusivamente religiose, e per di più formulate col linguaggio tipico di San Paolo, universale ed eterno, ma inattuale (in senso stretto). (2025)

Similar, in some ways, to the Appunti per un'Orestiade africana and its temporal structure, ${ }^{6}$ San Paolo is not so much a dialogue between present time and past time, the present and the tradition. Nor is it about two different historical layers. Rather, one should speak of the distinction between a 'world of history with an excess of presence and urgency', on the one hand and a religious, eternal, or 'metahistorical' 
and universal language, on the other. ${ }^{8}$ According to Pasolini, seen individually, each side is abstract: ' $[\mathrm{I}] 1$ mondo della storia [...] tende, nel suo eccesso di presenza e di urgenza, a sfuggire nel mistero, nell'astrattezza, nel puro interrogativo' (2025). And sanctity (la santità), 'il mondo del divino', also appears, taken by itself, as religious abstraction.

The unmediated confrontation of 'attualità's and sanctity, in contrast, should lead to what Pasolini described as follows: 'Il mondo divino discende tra gli uomini, si fa concreto e operante' (2025). 'Discendere' is a religiously loaded term, closely connected to the Incarnation in particular, but also to Christ's harrowing of hell. The immediate connection of historicity and eternity could thus be defined as a technique of concretion or incarnation, and Pasolini's San Paolo could be understood as the Christian counterpart to what Walter Benjamin called 'Jetztzeit': while Benjamin's 'Jetztzeit' is an igniting, powerful connection of a certain topicality or currentness ('das Aktuelle') in the past with the present time, ${ }^{10}$ Pasolini was interested in a sort of explosive connection of eternity and present time, an unmediated and abrupt connection which allows for the eternal language to irritate and thus influence the present, but not vice versa.

This abrupt connection has two effects: on one hand, it allows for keeping the eternal language separated from its modifying effects, saving eternity from mundane history. On the other hand, however, somewhat akin to Karl Barth's famous interpretation of Paul in Der Römerbrief from 1919, it is exactly the split between eternal and historical levels which, according to Pasolini, creates a tension between the two, concretizing them reciprocally. Keeping both levels separated is precisely the condition of possibility for the eternal responses' modifying reality, even though these modifications cannot be seen as their necessary consequences. In other words, focusing on Pasolini's San Paolo, we could say that it is exactly the radical separation of 'sanctity' and 'history' that preserves both the 'purity' of the eternal answers and their disturbing power: 'E quanto più 'santa' è la sua risposta, tanto più essa sconvolge, contraddice e modifica la realtà attuale’ (2030).

This tension between eternity and present time is accompanied by another, much more difficult and complicated, one - the tension within Pasolini's Paul. As was the case in other adaptions of classical subjects like his Edipo Re, written a little bit earlier than the first draft of San Paolo, Pasolini obviously used his own inner disruptions as a key for 
the interpretation or construction of Paul. The saint is thus - like Pasolini - a deeply divided or split man.

Paul's life, as described by Pasolini, is tripartite. First, he is presented as a severe, fanatic, fascist, law-abiding pharisaic persecutor of the Jews. Paul's severity against the Jews corresponds with a severity against himself - more precisely against a suggested repressed homosexuality. Paul's famous 'thorn in the flesh' (II Cor. 12, 7) is interpreted by Pasolini as a cipher of homosexuality. A homosexual desire - perhaps its very beginning - is already suggested in the Dream of the Macedonian, with the appearance of 'una figura bellissima: è un giovane tedesco biondo, forte, giovane' (2028), and then mentioned more explicitly in another dream, introduced in 1974:

Infine con i ragazzi più grandi fanno delle gare. Poi dentro gli spogliatoi si spogliano nudi davanti agli occhi dei ragazzini e di Paolo. Al ritorno a casa Paolo si sente male. È preso dalle convulsioni. Le stesse che lo perseguiteranno per tutta la vita. (1934)

Secondly, we have the Paul of mystical experience and conversion, a condition which I will argue is related to his state of blindness after the Damascene conversion, a phase of vulnerability and dependency.

Thirdly, the event not only failed to integrate Paul but it even increased a split which was latent before. The result is a tension between 'transumanar' and 'organizzar', between a convulsive frankness and an unaware dishonesty: 'Egli vive in uno stato di inconsapevole insincerità, che, nella sua anima fatta per essere sincera fino allo spasimo, si fa tensione quasi folle' (2026). We have a Paul split by the Damascene event. On one side, he appears as a fascinating, but also weak or ill, mystic and saint; on the other side, we have the return of the old fascist in form of the energetic, powerful organizer. In order to sharpen or intensify the tension as much as possible, Pasolini used perhaps unconsciously, but with a good intuition - the pseudo-Pauline letters to accentuate the organizer and primarily the authentic ones to accentuate the mystical Paul. ${ }^{11}$

I want to focus now on the Damascene conversion because it is here, in the direct confrontation of the pharisaic/fascist and the Christian/antifascist, of the persecutor and the persecuted, that we can hope to understand Paul's split better.

In the scene immediately before the Damascene conversion, Paul appears as Jew and Pharisee: 'circumcised on the eighth day, of the peo- 
ple of Israel, of the tribe of Benjamin, a Hebrew of Hebrews; as to the law, a Pharisee; as to zeal, a persecutor of the church; as to righteousness under the law, blameless' (Phil. 3, 5-6). ${ }^{12}$ Pasolini, who wrongly attributes these words to the Acts, proceeds: 'Queste parole Paolo pronuncia - con la sua faccia fanatica di fascista - davanti a un capo degno di lui: un alto ufficiale dell'esercito o un potente burocrate' (1893).

The Damascene conversion and its immediate consequences are described in the subsequent scenes: In scene 11, Paul feels suddenly unwell, hears a voice, and goes blind. In scene 14, Anania hears a voice as well and goes to Paul (scene 16), who regains his sight, looking around 'in a severe way' ('duramente', 1898). The question is how to interpret Paul's severe gaze (which is an invention by Pasolini) after the period of blindness, and how to relate it to the conversion.

According to Armando Maggi, 'the apostle regains his sight when he embraces the order of God (Jesus), whose threatening and reproaching voice he first heard before going blind. [...] God's stern and severe language has opened the apostle's eyes. They now share the same intolerant gaze. ${ }^{, 13}$ Maggi thus relates the severity of the gaze directly to the voice Paul heard in the moment of his conversion.

But who exactly is speaking to Paul? Here Pasolini combines Jesus and God, and Maggi seems to assume that there is no relevant difference between them when he uses the expression 'God (Jesus)'. Such a connection appears deceptively obvious for those who are used to a Trinitarian conception of God. However, the anachronistic reinscription of the result of long theological debates (the Trinitarian understanding of God) into a relatively early text, the Acts of the Apostles, would be odd, especially for Pasolini who blamed the Acts for already being too theologized. ${ }^{14}$ After all, on closer inspection, Pasolini doesn't mix God and Jesus, and Paul doesn't encounter 'God (Jesus)', God and Jesus; rather, he encounters God appearing as Jesus: 'Dio: Io sono quel Gesú' (1895). This 'God' is directly recognizable neither for Paul nor for the reader of the Acts (where it is Jesus who speaks to Paul and not God); here, God is Pasolini's addition.

This mimicry, however, cannot but recall a similar one which takes place almost immediately after this appearance, when the voice of God is heard again, this time by Anania:

Sul corpo dormente di Anania, si sente una voce. È Dio. 'Anania!' 'Eccomi, Signore!' (...) 'Vai, come ti dico, da quest'uomo che io ho scelto strumento 
idoneo per far conoscere il mio nome ai gentili, ai re, e ai figli di Israele. Io gli mostrerò quanto dovrà patire per il nome mio.' (1896)

These two scenes are closely connected. We have here two appearances of God: the first time he appears to Paul (as Jesus), the second time to Anania, to whom he mentions his appearance to Paul shortly before. But what is striking here is that it was apparently not God whom Anania supposedly encountered. Rather, it seems to have been the devil pretending to be God, as is explained in the words commenting upon the scene: 'Voce del diavolo che finge di essere Dio. Scena tra i diavoli' (1897).

It is, in consequence, not easy to avoid the conclusion that the devil who appeared to Anania as God had also already appeared, as he himself claimed, to Paul as Jesus shortly before. In this case, in his Damascene conversion Paul didn't encounter Jesus, but rather the devil. This is how Arcangelo Sacchetti, for example, reads it:

Insomma la 'vocazione sulla via di Damasco' e la conseguente missione a cui è destinato Paolo vengono avvolte da un'ombra satanica, che lascia intravedere da chi 'veramente' sia stato chiamato il 'fariseo fondatore', e per che cosa. ${ }^{15}$

Pasolini actually seems to open the possibility of a radically negative reading of the God who appeared to Paul (and thereby of his conversion and the very beginning of the church and/or of the mission of the Gentiles.) ${ }^{16}$ Moreover, after the words 'Io sono quel Gesù che tu perseguiti', he goes on in a tone which might somehow recall the one he showed in front of Anania: 'Ma ora alzati, va' in città e ti sará detto quello che devi fare' (1895).

Here, however, it is difficult to decide if this tone should be described as commanding, or if it is rather encouraging. The latter interpretation opens the possibility of a completely different reading from that of Maggi, and this seems necessary if we want to avoid that reading's highly problematic consequences. To describe, as Maggi does, the voice of 'God (Jesus): "Paolo, Paolo, perché mi perseguiti?"” as 'threatening', 'reproaching', connecting it to the 'intolerant gaze' of God, amounts to accusing the victims of persecution - the Christians, or, in the twentieth-century analogy proposed by Pasolini, the Jews - of having been 'threatening' and 'intolerant' towards their persecutors. It amounts, in other words, to accusing not the persecutors, but instead 
their victims. Apart from that, demonizing the words of the persecuted and of Jesus doesn't seem to correspond well to Pasolini's positive understanding of the historical figure of Jesus (as for example demonstrated in his film on Jesus, Vangelo secondo Matteo), nor with his sensitivity towards the persecuted in general.

This means that we have to maintain the clear difference between Jesus and the devil, but, in consequence, we have to preserve a difference between God who appeared to Paul as Jesus and the devil who also appeared to Anania. At the same time, we have to take into account the fact that Pasolini obviously wanted to suggest not the identity, but rather the proximity, between a Christian God and the devil that only later appeared; the question arises what Pasolini intended by this. I will try to suggest an answer to this point in the second section of this paper.

Against this background, we can try to understand the moment of Paul's conversion differently from Maggi as well as Sachetti: in the Damascene event, Paul encountered neither the severe and threatening voice of God (Maggi), nor the voice of Satan (Sachetti), but rather God with the voice of Jesus who in turn represented the voice of the Christian/Jewish victims of persecution. This voice of Jesus in the complete silence somewhere between France and Spain resembles the one Paul had already heard before - namely Saint Stephen's words of forgiveness ('parole di perdono', 2026) during his martyrdom, when Paul was present as persecutor ('presente all'esecuzione, a rappresentare l'ufficialità, che crede, in tal modo, di liberarsi della verità che viene a distruggerla', 2026). Since in his journey to Damascus/Barcelona, Paul was again acting as a persecutor in the name of his Jewish God, his immediate hearing of the voice of the persecuted (through Jesus) had to be consistent with the radical change of his God and thus with a shattering, groundbreaking experience.

Pasolini combines the Damascene conversion with Paul's sickness that immediately preceded it ('perduto nel suo malore', 1894) - and this seems to me one of his most original contributions here. In doing so, he suggests the possibility of understanding Paul's conversion in an additional sense: since Pasolini interprets the 'malore', the 'thorn in the flesh', as a cipher of homosexual desire and as an element of weakness in Paul, we could connect this reappearance of his sickness with the subsequent conversion. It is, one could say, the moment of weakness that allows Paul suddenly to perceive the voice of the persecuted. And it 
is, in turn, this traumatic appearance of a new God, the inversion of weakness, which in consequence allows Paul to face his own 'weaknesses', i.e. his homosexual desire. If, at least for a moment, the voice of God was equivalent to the one of Jesus ('Io sono quel Gesú che tu perseguiti', 1895), whose voice was for its part equivalent to that of the people whom Paul was persecuting, and if the (persecuted) enemy could be understood as a representation of Paul's own deep question (in the sense of Theodor Däubler's famous 'Der Feind ist unsere eigne Frage als Gestalt'), then the immediate confrontation with the perspective of the persecuted could become equivalent to a shocking and immediate confrontation with his repressed 'weak' side. Paul's conversion could thus be understood, as I will try to demonstrate later, as an abrupt 'aspect change' to the side of the oppressed Jewish Christian victims as well as to a repressed homosexual aspect within him.

This interpretation helps us avoid another problematic consequence of Maggi's reading. If God, who appeared to Paul, was already severe and intolerant, than in the Damascene conversion no relevant change occurred (except for a short period of blindness), since Paul was already severe and intolerant before the conversion. In consequence, the Paul who recovered after the conversion would not be different from the one who came before. After his conversion, Paul (as described by Pasolini) is indeed a severe, powerful priest and organizer. But this is only one side. The other consists in the mystical or loving or weak Paul. Arguably, Pasolini might even suggest a first homosexual love experience immediately after the conversion. An amorous encounter ('Paolo e Anania si dividono la stessa povera stanzuccia e lo stesso letto: dormono, uno da capo e uno da piedi', 1899) and an even longer period of amorous relations after the Damascene conversion ('Paolo è condotto per mano da Barnaba per le vie di Parigi', 1901) might be read in these indications, and the context and the connection with similar motifs in other works of Pasolini could provide additional plausibility: a similar combination of motifs of dependency and caress (blindness and handholding) is, for instance, described in Pasolini's Edipo Re, a film that is usually designated as particularly autobiographical, where the amorous relation appears slightly more evident. In both cases, Pasolini seems to suggest a (limited) period of love, an intermediate phase of integration and harmony, which is, however, destined to remain transitory and precarious in our societies. 
We should, however, avoid attributing homosexuality, as described by Pasolini, exclusively to the weak or mystical side of Paul and the repression of homosexuality to the severe priest and founder of the Church. Already the combination of a homoerotic dream with the powerful young (Nazi?)-German (in the dream of the Macedonian) indicates a certain ambiguity. This ambiguity becomes evident in the connection between the powerful preacher and the seducer Paul as depicted in scenes 41 and 42, which directly follow Paul's rupture with his friend Barnabas.

Gli occhi di Paolo, parlando, si posano su quel giovane, e lo notano. [...] Il ragazzo forse si è accorto di essere osservato da Paolo, e lo guarda, intimidito, sconvolto, con ancora maggiore attenzione. [...] Parlando, Paolo ancora osserva il ragazzo, che ricambia sempre più confuso e irrigidito, lo sguardo. [...] Paolo si avvicina al giovane che aveva osservato parlando - e che è rimasto ancora lì, tenendo ancora, meccanicamente, per mano la sua ragazza.

Paolo: 'Mi vuoi seguire?'

Il ragazzo risponde precipitosamente, senza neanche pensarci: 'Sì'. [...]

'Ma prima ti circonciderò - anche se ciò è in contraddizione con quanto sostegno - per riguardo agli ebrei di questa città, che ti sanno di padre greco'. Il ragazzo lo guarda obbediente. In Paolo c'è la prepotenza del capo. (1926-28)

I would argue that, in this passage, an indicated homosexual seduction is connected to the Paul's relation, as a preacher, to power as well as to his fall back to circumcision. In other words, homosexuality, as well as the figure of Paul, is split between a power-related aspect and a 'mystical', receptive or weak side. ${ }^{17}$

There is, however, another aspect of the severe, power-related side of the split Paul, which might create some irritation. As I already said, in the precarious moment of his conversion, Paul experienced God for an instant as different from the severe for being he was fighting till then. Shortly after the conversion, God appears as devil. How can we understand this change?

In his constant striving to exacerbate every possible split into a binary opposition, Pasolini was very interested in dramatizing the split between the two sources regarding Paul: the Acts (traditionally, and also by Pasolini, attributed to Luke) and the Letters (written by or attributed to Paul). In his version from 1974, Pasolini sharpened this 
split once again by introducing the devil and imagining that he took the place of Luke. ${ }^{18}$ And it is Luke who is held responsible for distorting the actions of Paul. Francesca Parmeggiani has detected here a deeper tension inside writing itself:

Pasolini sembra voler eliminare il momento della scrittura di Paolo per esaltare il conflitto ed approfondire la distanza tra parola santa, orale e non ancora pienamente cifrata, e la parola 'attuale', scritta, razionalizzata e falsificante. Sottolineando la funzione documentaria di Luca, può ridimensionare il valore della testimonianza scritta di Paolo, ossia le Lettere, che recupera ed evidenzia a livello strutturale come modello per la parola santa, orale ed ispirata dell'apostolo, per la sua predicazione. Le lettere sono infatti parola viva, colta nel momento della sua enunciazione e del confronto con chi la recepisce. ${ }^{19}$

This phonocentric understanding of writing, ${ }^{20}$ which is usually connected with an anti-Jewish interpretation of the 'dead letter', along with Pasolini's negative picture of Paul's relapse into the order of circumcision, makes clear that his irritating identification of the Pharisees with the collaborationists was not merely the result of unfortunate collateral damage from the transfer of Paul into the twentieth century, but rather drew on different anti-Jewish figures in his San Paolo.

If this is correct, the awkward question arises whether what Pasolini describes as the severe and pragmatic side of the split Paul was nothing but the return of the Pharisee and the change of God in devil nothing but the return of the Jewish God inside Christianity. Can we avoid the consequence that in the core of Paul's split, as described by Pasolini, we find a sort of battle between the experience of Jesus and the victims (and by this the possibility of a new understanding of God) on the one hand and the return of the Jewish God of Law as demon on the other, and that Pasolini's own problem with Paul and the Church is closely connected to the return of Judaism inside Christianity?

\section{THE PAULINE CONVERSION UNDERSTOOD AS ASPECT CHANGE}

Let me briefly summarize the argument of the first section. The Damascene conversion, as described by Pasolini, can be seen as the decisive turning point from which we can understand the central moments of Paul's development: the 'pharisaic' severity (in which weakness was 
inscribed) before the conversion; the encounter with the repressed (with Jesus and a new God) during the conversion; the split between this new (love) experience and his position as the powerful organizer of the Church after the conversion.

However, what still remains somehow unclear is the reason for the persistence and even aggravation of the initial tension in a split condition after the conversion. As ordinarily and trivially understood, conversion is supposed to lead the new believer to a completely new life and permit him to leave his former one behind. At least in the case of Pasolini's Paul, conversion seems to lead instead to an aggravation of the tension, to the splitting of Paul into two very different sides - and one aspect of this aggravation seems to be the change just mentioned of the Jewish God into a devil. If we manage to understand better the reason for this aggravation, we can hope to understand this (at least apparently) irritating aspect of Pasolini's San Paolo as well.

For the analysis of the connection between Paul's conversion and his split, I want to use the model of aspect change of 'multistable figures' or Kippbilder that I developed in more detail elsewhere. ${ }^{21}$ Here I will only summarize the key points of this model: in Kippbilder, for example in the famous image that can be seen either as a duck or a rabbit, we find two aspects shifting from one to the other, which are somehow connected but which remain symbolically strictly separated. Prima facie, the relation among the aspects is both symmetrical and circular, without linearity or progress, only the endless change from one aspect to the other. Seen in a genealogical way, it looks different: we have first a whole picture and then, after we see the 'second aspect', two relativized aspects. However, we do not first have a unity which is then simply divided into two (aspects); rather, we have first a whole and then the sudden introduction of a 'new' aspect which is not connected with the 'first aspect' except through its power to transform the whole retrospectively into an aspect. The first aspect change is the moment of a break, a division, which changes everything. After this retroactive and reciprocal 'aspectualization' (of the former whole, but also of the new aspect which appears as a relativized aspect only because of its relation to the 'first aspect'), the original whole vanishes, disappears, and is present only as the reminder of something lost. In this sense, the initial wholeness appears neither as purely constructed (before there was indeed an integrity, a whole in the form of an image) nor as something that was 
simply already there (what appeared as integrity and wholeness in fact turned out to be merely limited). ${ }^{22}$

We should underline that the wholeness has not only become inaccessible and perhaps an object of desire in the very moment of its disappearance, but also that there is a constant danger of imagining it in the shape of what once appeared to be an integral whole but turned out to be only an incomplete aspect. While denying the integrity altogether doesn't take into account the former existence of integrity, its visualization tends to be bound to the lost image and consequently falls into the totalitarian trap. But the new aspect might become the object of desire as well. It represents the appearance of something new which, at the same time, splits the former condition. In a quite opaque, but also fascinating, way (which cannot be analysed here), the new aspect combines the split with something new. Since the new aspect can be identified with the split, it can also be identified with the new condition (the split whole) and is thus both: particular and representative of the whole.

Only the first aspect change bears the quality of a 'Eureka!' moment, while all the others which follow appear as a normalized and banal repetition of the same, even though they are necessary to prevent the Kippbild from finally stabilizing in one aspect or another, thereby reducing the split and transforming a limited aspect into an (ambiguous, totalitarian) whole. In order to cover the complexity of the aspect change, we have to understand the first 'aspect change' as a splitting moment which bears the intensity of the combination of rupture and the appearance of something new (and which thereby represents the new split whole), but which at the same time creates the desire for a lost (unsplit) whole. Nevertheless, we also have to distinguish this first aspect change from a normalized, endless and senseless alternation of aspects.

Between the dramatic first aspect change and the normalized one, there is another relevant aspect change which mediates between both. The Kippbild as Kippbild doesn't start immediately with the experience of something new, the first aspect change, but rather with the 'return' to the 'first aspect' (which indeed is not a return, but a change into something new, insofar as it is, again, not the return to a whole, but to a relativized aspect). Only in this moment can we really start speaking of a Kippbild, because as long as there is no 'return', the whole dynamics of the aspect change is not yet developed; instead, we have a change from one state to another. The second aspect change initiates the normaliza- 
tion of the dramatic 'Eureka!' moment into the endless repetition of aspect changes.

We have now enough elements for a more formal understanding of the conversion of Pasolini's Paul - and especially for an understanding of his subsequent split condition. First of all, the Kippbild model allows for an understanding of Paul's conversion as both a confrontation with something new (a perception of the voice of the oppressed/repressed and of his own repressed side via Jesus, as well as the experience of a new God in the shape of Jesus) and as a splitting of his former condition, his former belief. The new aspect is at the same time, in its very beginning, a new aspect. It is related to and relativized from the former condition. The conversion, understood as a dramatic existential form of aspect change, is not the beginning of a completely new life. After the conversion, Paul is indeed a new person, but only in the sense that he is split between his old faith, which turned out to be particular, and the experience of something new. As in the case of 'aspect change', the Damascene event introduces the impossibility of returning to a previous whole or integrity, but it creates at the very same time both the desire for this wholeness/integrity as the lost object (God) and the desire for the new which is, however, strictly connected with the experience of the split (Jesus as well as God as split).

Pasolini's Paul seems to be trapped in this very dilemma: he cannot get rid of the former integrity, his former God, even though this God turned out to be particular and thus no God at all. Here, the irritating transformation of the former (Jewish) God into the devil appears more intelligible. It is not the Jewish God of the Jews who turned out to be the devil, but it is rather the Jewish God after a splitting experience (after the split or aspect change) who (because of this relativization) cannot but reappear as demon, as a totalitarian particularity. Believing in 'God' after the experience of his particularity is equivalent to what I described as the second aspect change and to what Pasolini called Paul's 'unaware dishonesty'.

At the same time, however, Paul cannot get rid of the experience of the new aspect (Jesus) either. This Jesus is connected with the experience of something new (love or caritas in relation to the victims of violence and oppression, as well as the introduction of a split). And, as we can see in his Vangelo secondo Matteo, Pasolini described Jesus exactly as a passionate loving man and as an intense political figure who split and divided his society rather than reconciling it. Pasolini stressed the 
famous words in Matthew 10, 34-35: 'Do not think that I have come to bring peace to the earth. I have not come to bring peace, but a sword.'

Instead of this tension between love and the split in the figure of Jesus, we have, in regard to Paul, a tension between dishonesty ('totalitarian' adherence to something particularized as whole, as God) and the experience of love and splitting. Split in his adherence to an ambivalent lost object and to the intensity of love and the split, the 'founder of the Church' is not able to make a decision, and this impossibility renews again and again the 'aspect change' and thus the split.

At the same time, Pasolini, as is so typical of him, introduces a further complication, since he seems to suggest that this very splitting of Paul was already the result of overcoming an impasse. His Paul could apparently overcome mystical blindness not through the Damascene event but through the re-deification of the relativized God and the ambivalent but empowering organizational work of Church-building. And even before, during the Damascene conversion, God's words ('ma ora alzati ...') could be described as somehow activating. In view of his Teorema, where it appears that no appropriate way out of a radical event is offered, ${ }^{23}$ we could even say that only this demonic and problematic return to a limited God, a lost integrity, allowed Paul to overcome the paralysis of his mystical blindness. At the same time, in maintaining the difference between a traumatic (love) event and what, from a Badiouian perspective, appear as its necessary consequences, Pasolini describes this organizational work as senseless or even negative, powerrelated acting. What the priest and organizer Paul does is, from its very beginning, a form of acting inspired by the devil, and, if it is necessary, then it is a senseless necessity, just a necessity: 'L'istituzione della Chiesa è stata solamente una necessità' (1919). Paul's further life oscillates in consequence between that of the follower of Jesus (allowing for taking the side of the repressed and so on) and that of the priest of a reduced, one-sided, deified 'integrity' and 'wholeness', the follower of a part pretending to be the whole.

\section{EPILOG UE}

I want to end this article by zooming out, coming back to my initial remarks and briefly comparing Pasolini's Paul with two interpretations by major Continental thinkers, Giorgio Agamben and Alain Badiou. 
For Badiou, Paul is a militant fighter for a universal event. ${ }^{24}$ This event is precarious, unstable; it is even a nothing, because it does not belong to any existing order or state, not even to the order of being. But this is exactly why it has to be realized through the continuous and steady inscription of its consequences in the existing world. ${ }^{25}$ And this is why his foundation of the Church appears for Badiou as not only legitimate but also inevitable - and even problematic decisions, coalitions, compromises, and the like, appear as necessary tactical decisions in a long militant fight for a change of the world.

Agamben's interpretation goes in a completely different direction. With respect to the idea of Paul as the founder of a new religion, the very beginning of Agamben's book on Saint Paul, Il tempo che resta, already states laconically:

In questo senso si può dire che vi è stata una sorta di sotterranea solidarietà fra Chiesa e la Sinagoga nel presentare Paolo come il fondatore di una nuova religione - qualità che con ogni evidenza egli, che aspettava a breve termine lo scadere del tempo, non si sarebbe mai sognato di rivendicare. ${ }^{26}$

This is also one reason why Agamben, who knew Pasolini personally (and even, as is well known, participated in Pasolini's film Vangelo secondo Matteo), and certainly knew his writing on Paul, didn't mention him at all in his book on Saint Paul: that tension or cut, which is crucial for Pasolini's understanding of Paul - between the saint and mystic of love and the pragmatic and indeed power-obsessed preacher and founder of the Church, or even, to radicalize the opposition, between Paul as 'founder of a repressive institution (the Church), and a prophet who announces the apocalyptic end of that institution ${ }^{27}$ - is almost irrelevant for Agamben. At the same time, Agamben's Paul is also split, but in a different way. Agamben uses the figure of the 'divisions of divisions' in order to explain Paul's central gesture: the split of the Christian event or splitting into an 'already' and a 'not yet', attaining in this way a position in between the two.

The divisions of divisions might be read as an ingenious means to legitimate one's preference for not being completely absorbed by the event, without neglecting it but without being willing to follow it. It can be seen as equivalent to timidity instead of making a clear decision, as a kind of 'castration of the cut', its melancholic deactivation in a neither/ nor, while a position like Badiou's - fully embracing the event with all 
its consequences - seems to be more consistent, sincere, and courageous.

From a different point of view, however, it is Agamben's approach that can appear as more radical. For Badiou, even if the event introduces a cut, it is clear that we have to make a decision (endorsing the event and thus becoming a subject of truth, or opposing it, becoming thereby an obscurantist or reactionary subject). For Agamben, instead, the cut makes it literally impossible to make a decision. In the moment that we are spilt, our integrity is lost and any attempt to regain it (be it traditionalist or progressive) is naive or hopeless.

Badiou has understood the difference between his position and Agamben's very precisely. In his Logiques des mondes, he marks it in the light of their diametrically opposed interpretations of Paul:

As usual, Agamben, taking all sorts of lexical precautions, carefully orients his thought towards his recurrent theme: being as weakness, as presentational poverty, as a power preserved from the glory of its act. His latent Christianity generates a kind of modern poetics, in which the open is pure exposition to a substance-less becoming. Likewise, in politics, the hero is the one brought back to his pure being as a transitory living being, the one who may be killed without judgment, the homo sacer of the Romans, the muselmann of the extermination camp (the expression was recorded by Primo Levi). The properly human community, communism, is what may come, never what is there. And Saint Paul, despite his foundational role, his assurance and his militancy is brought back-via a single opaque phrase from the Epistle to the Romans - to the tremblings of messianism, in a paradoxical kinship with Walter Benjamin. Without a doubt, nothing makes it easier to judge what sets us apart (notwithstanding our friendship) than the gap between our respective books on the apostle. ${ }^{28}$

And Pasolini? Is it not striking that both opposing possibilities of interpreting Paul, militant subject of a universal event and its necessary consequences here, softness, weakness, poverty, homo sacer there, or, to put it with Alexander Kluge, 'gepanzerter Charakter' ('shielded character') and 'schutzlos auf die Nichtbeachtung der Realität geeicht'29 ('defencelessly programmed for disregarding reality'), fit so well with the two aspects of Pasolini's Paul? In other words: while it is - interestingly enough - the earliest Christian thinker who splits two major figures of contemporary leftist thought, Badiou and Agamben, in the most evident way, it is his namesake Pasolini whose deeply split Paul represents a dichotomy which disunites them in the core. 
1 According to Benjamin, every work and every writing has a specific historical index and is not only connected to the very moment of its appearance but also to a special other moment of readability in its future. See Walter Benjamin, 'Zentralpark', in Gesammelte Schriften, ed. by Rolf Tiedemann and Hermann Schweppenhauser, 7 vols (Frankfurt am Main: Suhrkamp, 1974-89), I/2 (1977), pp. 655-90 (p. 682). Agamben used Benjamin's notion of the 'Jetzt der Erkennbarkeit', 'now of readability', in order to illuminate Paul's specific current relevance. See Giorgio Agamben, Il tempo che resta: Un commento alla Lettera ai Romani (Turin: Bollati Boringhieri, 2000), pp. 134-35.

2 Ibid, p. 13. See also Jacob Taubes, Die politische Theologie des Paulus: Vorträge, gehalten an der Forschungsstätte der evangelischen Studiengemeinschaft in Heidelberg, 23.-27. Februar 1987 (Munich: Wilhelm Fink, 1993), p. 12.

3 I use the term 'San Paolo-project' to refer to the script 'Abbozzo di sceneggiatura per un film su San Paolo', written in 1968 and supplemented in 1974, and the short description 'Progetto per un film su San Paolo', probably written in 1966. See Walter Siti and Franco Zabagli, 'Note e notizie sui testi', in Pier Paolo Pasolini, Per il cinema, ed. by Walter Siti and Franco Zabagli, 2 vols (Milan: Mondadori, 2001), II, p. 3154. 'Abozzo' as well as 'Progetto' will be quoted from Per il cinema, pp. 1881-2030.

4 Armando Maggi, The Resurrection of the Body: Pier Paolo Pasolini from Saint Paul to Sade (Chicago: University of Chicago Press, 2009), calls San Paolo Pasolini's 'most direct and sincere self-portrait, his most explicit autobiography' (p. 22).

5 One aspect of this split is the stark contrast between what we hear (at least regarding the ancient words of Saint Paul) and what we see (the modern world). See ibid., p. 38.

6 See Manuele Gragnolati, 'Analogy and Difference: Multistable Figures in Pier Paolo Pasolini's Appunti per un'Orestiade africana' in this volume.

7 See Pier Paolo Pasolini, Pasolini on Pasolini, ed. by Oswald Stack (Bloomington: Indiana University Press, 1969), p. 127, as cited in Francesca Parmeggiani, Lo spessore della letteratura: Presenze neotestamentarie nella narrativa italiana degli anni Sessanta e Settanta (Ravenna: Longo, 2007), p. 39.

8 This distinction corresponds with what Silvia Mazzini nicely describes as Pasolini's perhaps characteristic tension 'between being up-to-date and being out-oftime'. See Silvia Mazzini, 'Pasolini and India: De- and Re-Construction of a Myth', in this volume.

9 The Italian term attualità means 'current times' as well as something which is considered relevant right now.

10 'Die französische Revolution verstand sich als ein wiedergekehrtes Rom. Sie zitierte das alte Rom genau so wie die Mode eine vergangene Tracht zitiert. Die Mode hat die Witterung für das Aktuelle, wo immer es sich im Dickicht des Einst bewegt. Sie ist der Tigersprung ins Vergangene. Nur findet er in einer Arena statt, in der die herrschende Klasse kommandiert. Derselbe Sprung unter 
dem freien Himmel der Geschichte ist der dialektische als den Marx die Revolution begriffen hat'; see Walter Benjamin, 'Über den Begriff der Geschichte', in Gesammelte Schriften, I/2 (1974), pp. 691-704 (p. 701).

11 See Reinhold Zwick, 'Nachwort', in Pier Paolo Pasolini, Der heilige Paulus, ed. and trans. by Reinhold Zwick and Dagmar Reichardt (Marburg: Schüren, 2007), pp. 157-85 (p. 168).

12 I quote the New Testament from the English Standard Version.

13 Maggi, The Resurrection of the Body, p. 64.

14 See Parmeggiani, Lo spessore della letteratura.

15 Arcangelo Sacchetti, 'Pasolini e il Sacro IV. Paolo di Tarso, fondatore e santo: La sceneggiatura per un film non fatto', Il sangue della redenzione: Rivista semestrale dei missionary; del prez[iosissi]mo sangue, 4.2 (July-December 2006), pp. 145-210 (p. 160); also available at <http://www.csscro.it/riviste/sangue0602. pdf> [accessed 4 April 2012].

16 Both options seem similar, can however lead to opposite results: identifying the voice Paul heard with the one of an intolerant God not only leads to a critical understanding of the Christian Church from its very beginning, but also to the possibility of interpreting it as negative because of the return of Judaism (the 'intolerant God of the Old Testament') under the cover of Christianity. Interpreting this voice as satanic, instead, might be read as demonic inspiration to the mission of the Gentiles. In this case, Christianity itself would appear highly problematic because of its missionary tendency to expand beyond Judaism.

17 This ambiguity becomes even more visible through the fact that it is exactly the seduced Timothy who becomes the early representative of an institutionalized Church. See Bruno Besana, 'Badiou's Pasolini: The Problem of Subtractive Universalism', in this volume.

18 This further split has implications regarding the temporal structure, since we have thereby an additional temporal layer between Eternity and Present which Maggi calls 'Present Past' (The Resurrection of the Body, pp. 38-39).

19 Parmeggiani, Lo spessore della letteratura, p. 53.

20 At the very same time, Jacques Derrida criticized this phonocentric understanding in his book De la grammatologie (Paris: Minuit, 1967). See also Luca Di Blasi, 'Grammatheologie: Eine kultur- und medientheoretische Lektüre', Deutsche Zeitschrift für Philosophie, 55 (2007), pp. 717-33.

21 For a more detailed analysis of aspect change, see my paper 'Splitting Images' in the volume Multistable Figures: On the Critical Potential of Ir/reversible AspectSeeing, ed. by Christoph F.E. Holzhey (Vienna: Turia+Kant, forthcoming).

22 The model of the Kippbild might also indicate the problem of a paradoxical identification of loss and acquisition, as is suggested again and again by Slavoj Žižek: 'the Fall ("regression" to the natural state, enslavement to passions) is stricto sensu identical with the dimension from which we fall, i.e., it is the very movement of the Fall that creates, opens up, what is lost in it'; see Slavoj Žižek, 'Dialectical Clarity versus the Misty Conceit of Paradox', in Žižek and John Milbank, The Monstrosity of Christ: Paradox or Dialectic? ed. by Creston Davis (Cambridge, MA: MIT Press, 2009), pp. 234-305 (p. 373). The same holds for 
the Hegelian synthesis which Žižek also strictly connects with division: 'die Synthese, die man jenseits der Entzweiung gesucht hatte, ist schon durch die Entzweiung selbst realisiert'; see Slavoj Žižek, Psychoanalyse und die Philosophie des deutschen Idealismus. I: Der erhabenste aller Hysteriker. II: Verweilen beim Negativen (Vienna: Turia + Kant, 2008), p. 44. The Kippbild, however, opens the possibility for another understanding: there was actually a wholeness of an image before the split, so that one cannot exactly say that the wholeness arose in the very moment of the split, even though, again, this wholeness retroactively turns out to have been limited. Transforming the split into the retroactive creation of wholeness means attributing too much to it.

23 In the film Teorema it is difficult to see any positive possibility of transforming the traumatic mystical experience into 'productive' acts. There is literally no way to deal with it. According to Graziella Chiarcossi (personal communication), Pasolini understood only Emilia's religious reaction as somehow a successful response to the event; here we might find a hint why, in contrast with Badiou, religion does not disappear in Pasolini. It is exactly the impossibility of finding a feasible path out of the traumatic, splitting experience that might leave the religious way open (the way of giving up any subjective attempt or arbitrary act Eigenmächtigkeit - and thus creating the condition of possibility for a trans-subjective encounter), even though Pasolini experienced himself as cut off from this religious possibility as well. '[S]ono bloccato, caro Don Giovanni, in un modo che solo la Grazia potrebbe sciogliere. La mia volontà e l'altrui sono impotenti. [...] Forse perchè io sono da sempre caduto da cavallo [...] e un mio piede è rimasto impigliato nella staffa, così che la mia corsa non è una cavalcata, ma un essere trascinato via, con il capo che sbatte sulla polvere e sulle pietre. Non posso né risalire sul cavallo degli Ebrei e dei Gentili, né cascare per sempre sulla terra di Dio"; see Pier Paolo Pasolini, letter to Don Giovanni Sossi, 27 December 1964, in Lettere, 1955-1975, ed. by Nico Naldini (Turin: Einaudi, 1988), p. 576. Many thanks to Hervé Joubert-Laurencin, who directed this text to the attention of Bruno Besana (from whom I appropriate the reference).

24 Badiou, Saint Paul.

25 See also Besana's essay in this volume.

26 Agamben, Il tempo che resta, p. 10.

27 Maggi, The Resurrection of the Body, p. 21.

28 Alain Badiou, Logics of Worlds: Being and Event 2 (London: Continuum, 2009), pp. 558-59.

29 Alexander Kluge, Das fünfte Buch: Neue Lebensläufe (Berlin: Suhrkamp, 2012), p. 366 . 
Luca Di Blasi, 'One Divided by Another: Split and Conversion in Pasolini's San Paolo', in The Scandal of Self-Contradiction: Pasolini's Multistable Subjectivities, Geographies, Traditions, ed. by Luca Di Blasi, Manuele Gragnolati, and Christoph F. E. Holzhey, Cultural Inquiry, 6 (Vienna: Turia + Kant, 2012), pp. 189-207 <https:// doi.org/10.37050/ci-06_11>

\section{REFERENCES}

Agamben, Giorgio, Il tempo che resta: Un commento alla Lettera ai Romani (Turin: Bollati Boringhieri, 2000)

Badiou, Alain, Logics of Worlds: Being and Event 2 (London: Continuum, 2009)

- Saint Paul: The Foundation of Universalism, trans. by Ray Brassier (Stanford: Stanford University Press, 2003)

Benjamin, Walter, Gesammelte Schriften, ed. by Rolf Tiedemann and Hermann Schweppenhauser, 7 vols (Frankfurt am Main: Suhrkamp, 1974-89)

Derrida, Jacques, De la grammatologie (Paris: Minuit, 1967)

Di Blasi, Luca, 'Grammatheologie: Eine kultur- und medientheoretische Lektüre', Deutsche Zeitschrift für Philosophie, 55 (2007), pp. 717-33 <https://doi.org/10.1524/dzph.2007.55. 5.717>

Kluge, Alexander, Das fünfte Buch: Neue Lebensläufe (Berlin: Suhrkamp, 2012)

Maggi, Armando, The Resurrection of the Body: Pier Paolo Pasolini from Saint Paul to Sade (Chicago: University of Chicago Press, 2009) <https://doi.org/10.7208/chicago/ 9780226501369.001.0001>

Parmeggiani, Francesca, Lo spessore della letteratura: Presenze neotestamentarie nella narrativa italiana degli anni Sessanta e Settanta (Ravenna: Longo, 2007)

Pasolini, Pier Paolo, Pasolini on Pasolini, ed. by Oswald Stack (Bloomington: Indiana University Press, 1969)

Per il cinema, ed. by Walter Siti and Franco Zabagli, 2 vols (Milan: Mondadori, 2001)

Sacchetti, Arcangelo, 'Pasolini e il Sacro IV. Paolo di Tarso, fondatore e santo: La sceneggiatura per un film non fatto', Il sangue della redenzione: Rivista semestrale dei missionary del prez[iosissi]mo sangue, 4.2 (July-December 2006), pp. 145-210 <http://www.csscro. it/riviste/sangue0602.pdf> [accessed 4 April 2012]

Taubes, Jacob, Die politische Theologie des Paulus: Vorträge, gehalten an der Forschungsstätte der evangelischen Studiengemeinschaft in Heidelberg, 23.-27. Februar 1987 (Munich: Wilhelm Fink, 1993)

Zwick, Reinhold, 'Nachwort', in Pier Paolo Pasolini, Der heilige Paulus, ed. and trans. by Reinhold Zwick and Dagmar Reichardt (Marburg: Schüren, 2007), pp. 157-85

Žižek, Slavoj, 'Dialectical Clarity versus the Misty Conceit of Paradox', in Žižek and John Milbank, The Monstrosity of Christ: Paradox or Dialectic? ed. by Creston Davis (Cambridge, MA: MIT Press, 2009), pp. 234-305 <https://doi.org/10.7551/mitpress/8208.001.0001>

_ Psychoanalyse und die Philosophie des deutschen Idealismus. I: Der erhabenste aller Hysteriker. II: Verweilen beim Negativen (Vienna: Turia + Kant, 2008) 